DOI: 10.38136/jgon.885490

\title{
Preeklampsi Hastalarında Tam Kan Sayımı Parametrelerinin Önemi
}

\section{The Importance of Complete Blood Count Parameters in Preeclampsia Patients}

\author{
İrem ALYAZICI KÜÇÜKYILDIZ
}

(1) Orcid ID:0000-0002-6604-0713

${ }^{1}$ Sivas Cumhuriyet Üniversitesi Tıp Fakültesi, Kadın Hastalıkları ve Doğum Anabilim Dalı, Sivas, Türkiye

\section{Öz}

Amaç: Preeklampsi, gebeliğin 20. haftasından sonra saptanan; yeni başlangıçı hipertansiyon ve organ disfonksiyonu ile karakterize, progresif, multisistemik bir hastalık olarak tanımlanmaktadr. Hafif ve şiddetli olmak üzere iki grupta değerlendirilebilen preeklampsi özellikle şiddetli formunda ciddi maternal, fetal, neonatal morbidite ve mortalite ile ilişkili olabilmektedir. Bununla birlikte preeklampsi etyolojisi ve prediktör faktörleri hala tam olarak aydınlatılabilmiş değildir. Biz çalışmamızda tam kan sayımı parametrelerinin preeklampsi tanısı ve şiddetini belirlemedeki önemini tespit etmeyi amaçladık.

Gereç ve Yöntemler: Çalışmaya 20 preeklamptik gebe ve 30 preeklampsinin eşlik etmediği sağ|ıkı gebe dahil edildi. Maternal ve fetal veriler ile birlikte doğum öncesi gebelerden rutin alınan tam kan sayımı parametreleri gruplar arasında karşılaştııılı. Bu parametreler hemoglobin, trombosit sayısı, ortalama trombosit hacmi, lökosit-lenfosit sayısı ve trombosit /MPV, nötrofil/lenfosit trombosit/lenfosit, trombosit /nötrofil oranlarını kapsamaktadır.

Bulgular: Çalışmamızda değerlendirilen kadınların ortalama yaşları preeklampsi grubunda $30( \pm 13,5)$ kontrol grubunda $27( \pm 11)$ idi. Kan sayımı parametreleri incelendiğinde; preeklampsi grubunda kontrol grubundan daha yüksek hemoglobin düzeyi tespit edilir iken; şiddetli preeklampsi grubunda ortalama trombosit hacminin hafif preklampsi grubu ve kontrol grubundan anlamlı olarak daha yüksek olduğu saptandı. Sonuç: Çalışmamızda şiddetli preklampsinin eşlik ettiği gebelerde ortalama trombosit hacminin daha yüksek olduğu saptandı. Bununla birlikte, inflamatuar belirteç olarak kabul edilebilen nötrofil/lenfosit, trombosit/lenfosit oranlarının gruplar arasında fark göstermediği bulundu.

Anahtar kelimeler: Preeklampsi; ortalama trombosit hacmi; nötrofil; trombosit; gebelik

\section{GíRiş}

Gebelikte hipertansif bozukluklar tüm gebeliklerin \%5-11 ini komplike haline getirmektedir $(1,2)$ ve maternal, fetal ve neonatal mortalitenin önde gelen nedenlerinden biridir. Gebelikte hipertansif hastalıklar genel olarak 4 gruba ayrılır; kronik hipertansiyon, gestasyonel hipertansiyon, preeklampsi, kronik hipertansiyona süperempoze preeklampsi. Preeklampsi (PE), gebeliğin 20. haftasından sonra saptanan; yeni başlangıçlı

\section{ABSTRACT}

Aim: Preeclampsia, which detected after the 20th week of pregnancy; is defined as a progressive, multisystemic disease characterized by new-onset hypertension and organ dysfunction. Preeclampsia can be evaluated in two groups as mild and severe, and associated with maternal, fetal, neonatal morbidity and mortality, especially in its severe form. Preeclampsia etiology and predictive factors are still not fully elucidated. In our study, we aimed to determine the importance of blood count parameters in determining the diagnosis and severity of preeclampsia.

Matirals and Methods: 20 preeclamptic pregnant women and 30 healthy pregnant women without preeclampsia were included in the study. Along with maternal and fetal data, routine complete blood count parameters taken from before delivery were compared between the groups. These parameters include hemoglobin, thrombocyte number, mean platelet volume, leukocyte-lymphocyte numbers and thrombocyte I MPV, neutrophil / lymphocyte thrombocyte / lymphocyte, thrombocyte / neutrophil ratio.

Results: When blood count parameters are examined; while a higher hemoglobin level was detected in the preeclampsia group than in the control group; It was found that the mean platelet volume in the severe preeclampsia group was significantly higher than the mild preeclampsia group and the control group.

Conclusion: In our study, it was found that the mean platelet volume was higher in pregnant women accompanied by severe preeclampsia. However, it was found that neutrophil / lymphocyte, platelet / lymphocyte ratios, which can be considered as inflammatory markers, did not differ between the groups.

Keywords: Preeclampsia; mean platelet volume; neutrophil; thrombocyte; pregnancy

hipertansiyon ve organ disfonksiyonu ile karakterize, progresif, multisistemik bir hastalıktır (3). PE'nin \%2-8 oranında gebeliklere eşlik ettiği kabul edilmektedir (3). Tansiyon yüksekliğine, sıklıkla yeni başlayan proteinüri eşlik etmesine rağmen, proteinüri yokluğunda trombositopeni, anormal karaciğer-böbrek fonksiyon testleri laboratuvar bulgusu olarak; görme bozuklukları, baş ağrısı ve epigastrik ağrı klinik belirtiler olarak karşımıza çıkabilmektedir $(3,4)$. PE'nin patofizyolojisi muhtemelen 
hem maternal hem de fetal - plasental faktörleri içerir ve preeklampsi patogenezinde birçok teori öne sürülmüştür. Anormal plasentasyon - plasental iskemi, immün maladaptasyon, endotel disfonksiyonu, artmış immünolojik ve inflamatuar yanıt preeklampsi oluşumunda en sık sorumlu tutulan mekanizmalardır( $3,5,6,7)$.

Endotel hasarı nedeniyle gelişen yaygın inflamatuar bir süreç olarak tanımlanan PE'de; lökosit ve nötrofilin rol oynadığı artmış inflamatuar cevap ve hasara uğramış endotelle temas eden trombositlerin koagülasyon sistemini aktive etmesi, trombosit yıkımı ve buna bağlı artmış üretimi saptandığı ileri sürülmektedir.

Gebelikte önemli bir oranda morbidite ve mortaliteden sorumlu olan PE'nin gelişimi ve sonrasındaki takibini sağlamak için öngörücü testlere intiyaç bulunmaktadır.

Hastalığın patogenezine dayalı olarak bu çalışmada, nötrofil/ lenfosit oranı (NLR), trombosit/lenfosit oranı (PLR), trombosit/ nötrofil oranı (PNR) gibi serum inflamatuar belirteçleri ve trombosit fonksiyonları hakkında indirek bilgiveren trombosit sayısı ve MPV (Ortalama trombosit hacmi ) parametreleri değerlendirildi. Çalışmamızda, tam kan sayımı parametrelerinin PE tanısı ve şiddetini belirlemedeki önemini tespit etmeyi amaçladık.

\section{GEREÇ VE YÖNTEMLER}

Çalışmamız Sivas Cumhuriyet Üniversitesi Etik Kurulu tarafından onaylandı (onay no:2020-10/14) ve Helsinki Bildirgesi'nde belirtilen esaslara göre yürütüldü.

Bu retrospektif çalışmada, üniversitemizde doğumu aynı hekim tarafından gerçekleştirilen 20 PE eşlik eden ve 30 sağlıklı gebeliği olan toplam 50 kadının sonuçları değerlendirildi. Hipertansiyon tanısı almamış ve proteinürisi olmayan sağlıkı tekiz gebeler kontrol grubunu oluşturdu.

PE tanısı normotansif bir gebede gebeliğin 20.haftasından sonra hipertansiyona (kan basıncının sistolik $\geq 140 \mathrm{mmHg}$ ve / veya diastolik $\geq 90 \mathrm{mmHg}$ ) proteinüri veya proteinüri olmasa bile, hipertansiyon ile birlikte trombositopeni (trombosit $<100.000 / 103$ $/ \mu \mathrm{L}$ ), bozulmuş karaciğer fonksiyon testleri (Karaciğer transaminazlarının kan değerlerinin normal konsantrasyonun iki katına yükselmesi), yeni başlayan böbrek yetmezliğinin olması (serum kreatinin değerlerinin $>1,1 \mathrm{mg} / \mathrm{dL}$ olması yada başka bir renal hastalık yokluğunda serum kreatinin değerlerinin iki kat artması), akciğer ödemi olması veya yeni başlayan serebral ve görme bozukluklarının olması durumunda konuldu. Proteinüri; 24 saatlik idrarda $\geq 300 \mathrm{mg}$ proteinüri olması veya protein/kreatinin Oranı $\geq 0,3$ olması ya da idrar çubuğu ile yapılan ölçümde 1+ proteinüri olması olarak kabul edildi. Şiddetli preeklampsi tanısı tansiyon değerleri sistolik $\geq 160 \mathrm{mmHg}$ ve / veya diastolik $\geq 110 \mathrm{mmHg}$ durumunda konuldu.

Maternal özellikler olarak kadınların yaşı, doğum sayıları, doğum yöntemi, gestasyonel hafta bilgileri; fetal özellikler olarak cinsiyet, doğum ağırlığı, 1.ve 5. dk Apgar skorları kayıt edildi. Aynı zamanda çalışmaya katılan kadınların doğum öncesi rutin olarak gönderilen tam kan sayımı sonuçları, spot idrar testleri ve karaciğer fonksiyon testleri değerlendirildi. Hemoglobin (mg/

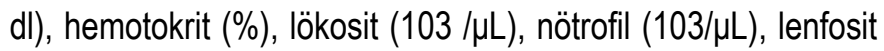

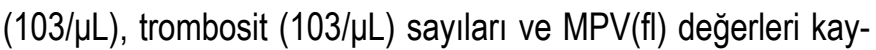
dedildi. Nötrofil/lenfosit, trombosit/lenfosit, trombosit/ nötrofil ve trombosit /MPV oranları hesaplandı ve kaydedildi.

İstatistiksel değerlendirme SPSS 22 yazıım programı ile yapıldı. Sayısal değişkenlerin dağılımını değerlendirmek için Kolmogorov-Smirnov testi kullanıldı. Tanımlayıcı ölçütler; ortalama dağılımı olarak sunuldu. Verilerin normal dağılıma uygunluğu sağlanamadığından iki kategorili değişkenlerin fark analizi Mann Whitney U testi ile hesaplanmıştır. Kategorik değişkenler ki-kare testi kullanılarak karşılaştıııldı. İstatistiksel anlamlılık düzeyi $p<0.05$ olarak kabul edildi.

\section{BULGULAR}

Çalışmamıza katılan 50 kadının, 20 si gebeliğinde PE tanısı aldı. Bu 20 gebenin \%70'i (n:14) şiddetli PE olarak değerlendirildi.

Çalışmamızda değerlendirilen kadınların maternal özellikleri gruplar arasında karşılaştıııdığında gebelik haftasının PE grubunda kontrol gruba göre istatistiksel anlamlı olarak daha düşük olduğu (p:0.017) ; anne yaşı, gravida, parite değişkenlerinin gruplar arasında farklı olmadığı saptandı (Tablo 1). PE grubunda 19 (\%95) hastaya sezaryen uygulandığı, kontrol grubunda ise 4 (\%46.7) hastaya sezaryen uygulandığı saptandı, PE grubunda sezaryen doğum şeklinin daha fazla olduğu görüldü (p:0.001). 
Tablo1: Anneye ilişkin özellikler

\begin{tabular}{llll}
\hline & Preeklampsi (n:20) & Kontrol (n:30) & P \\
& Ort (IQR) & Ort (IQR) & \\
\hline Anne yaş1 & $30(13.5($ & $27(11)$ & 0.532 \\
Gravida & $3(3)$ & $2.5(3)$ & 0.716 \\
Parite & $2(3)$ & $1(3)$ & 0.775 \\
Gebelik haftas1 & $36.3(3)$ & $38.75(3)$ & $\mathbf{0 . 0 1 7}$ \\
\hline
\end{tabular}

Ort(IQR): Verilerin ortanca değerleri (Çeyrekler arası aralık)

Fetal özelliklerin değerlendirilmesinde PE grubunda kontrol gruba göre daha düşük bebek kilosu, 1. ve 5. dk Apgar skorları saptandı ( $p<0.001, \mathrm{p}: 0.019, \mathrm{p}: 0.014$ ) (Tablo 2).

Tablo 2: Bebeğe ilişkin özellikler

\begin{tabular}{llll}
\hline & Preeklampsi (n:20) & Kontrol (n:30) & P \\
& Ort (IQR) & Ort (IQR) & \\
\hline Bebek kilo(g) & $2447.5(1032)$ & $3415(510)$ & $<\mathbf{0 . 0 0 1}$ \\
1.dk Apgar skoru & $7(2)$ & $8(1)$ & $\mathbf{0 . 0 1 9}$ \\
5.dk Apgar skoru & $8(1)$ & $9(1)$ & $\mathbf{0 . 0 1 4}$ \\
\hline
\end{tabular}

Ort(IQR): Verilerin ortanca değerleri (Çeyrekler arası aralık)

Kadınların doğum öncesi rutin alınan kan testleri gruplar arasında karşılaştıııldığında sadece hemoglobin değerinin istatistiksel anlamlı olarak PE grubunda daha yüksek olduğu bulundu (Tablo 3).

Tablo 3: Tam kan sayımı, karaciğer fonksiyon testleri ve tansiyon sonuçlarının değerlendirilmesi

\begin{tabular}{llll}
\hline & Preeklampsi (n:20) & Kontrol (n:30) & P \\
& Ort (IQR) & Ort (IQR) & \\
\hline Hemoglobin $(\mathrm{mg} / \mathrm{dl})$ & $13.15 \pm 1,55$ & $11.75 \pm 1.80$ & $\mathbf{0 . 0 0 1}$ \\
Lökosit $\left(10^{3} / \mu \mathrm{L}\right)$ & $11.10 \pm 3.72$ & $10.59 \pm 3.22$ & 0.566 \\
Lenfosit $\left(10^{3} / \mu \mathrm{L}\right)$ & $2.55 \pm 2.13$ & $2.56 \pm 2.42$ & 0.593 \\
Nötrofil $\left(10^{3} / \mu \mathrm{L}\right)$ & $8.37 \pm 3.67$ & $7.72 \pm 2.69$ & 0.649 \\
Trombosit( $\left(10^{3} / \mu \mathrm{L}\right)$ & $228 \pm 107$ & $246 \pm 69$ & 0.649 \\
MPV (fl) & $11.45 \pm 1.25$ & $10.7 \pm 1.20$ & 0.103 \\
Nötrofil/Lenfosit & $2.50 \pm 1.77$ & $2.62 \pm 2$ & 0.707 \\
Trombosit/Lenfosit & $91.21 \pm 55.57$ & $85.38 \pm 63.39$ & 0.812 \\
Trombosit/Nötrofil & $31.33 \pm 14.25$ & $32.48 \pm 12.67$ & 0.649 \\
Trombosit/MPV & $19.84 \pm 10.34$ & $23.75 \pm 7.03$ & 0.255 \\
AST & $17.5 \pm 11.50$ & $12.5 \pm 10$ & 0.073 \\
ALT & $11.5 \pm 7.50$ & $12 \pm 5$ & 0.356 \\
Sistolik Kan basin- & $160 \pm 20$ & $110 \pm 10$ & $<\mathbf{0 . 0 0 1}$ \\
c1(mmHg) & & & \\
Diastolik Kan basin- & $100 \pm 20$ & $70 \pm 10$ & $<\mathbf{0 . 0 0 1}$ \\
c1(mmHg) & & & \\
\hline
\end{tabular}

Ort(IQR): Verilerin ortanca değerleri (Çeyrekler arası aralık)

Ancak şiddetli PE'si grubu, kontrol grup ile karşılaştırıldığında; $P E$ grubunda maternal doğum öncesi hemoglobin değeri ile birlikte MPV değerinin de anlamlı olarak yüksek olduğu saptandı (Tablo 4).
Tablo 4: Şiddetli Preeklampsi- Hafif Preeklamsi; Şiddetli Preeklampsi-Kontrol gruplarında değişkenlerin karşılaştırıması

\begin{tabular}{lllllll}
\hline & $\begin{array}{l}\text { Şiddetli Pre- } \\
\text { eklampsi }\end{array}$ & $\begin{array}{l}\text { Hafif Preek- } \\
\text { lampsi }\end{array}$ & & $\begin{array}{l}\text { Siddetli Pre- } \\
\text { eklampsi }\end{array}$ & Kontrol & P \\
& Ort (IQR) & Ort (IQR) & & Ort (IQR) & Ort (IQR) & \\
\hline Yaş & $33 \pm 10$ & $22.5 \pm 3$ & 0.016 & $33 \pm 10$ & $27 \pm 11$ & 0.073 \\
Gravida & $4 \pm 4$ & $1.5 \pm 2$ & 0.043 & $4 \pm 4$ & $2.5 \pm 3$ & 0.205 \\
Parite & $2 \pm 3$ & $0.5 \pm 2$ & 0.086 & $2 \pm 3$ & $1 \pm 3$ & 0.301 \\
Gebelik haftas1 & $35.8 \pm 3$ & $38 \pm 4.5$ & 0.198 & $35.8 \pm 3$ & $38.75 \pm 2.60$ & 0.006 \\
Bebek kilo & $2257.5 \pm 689$ & $2945 \pm 1575$ & 0.248 & $2257.5 \pm 689$ & $3415 \pm 510$ & $<0.001$ \\
1.dk Apgar & $7 \pm 2$ & $7 \pm 0$ & 0.731 & $7 \pm 2$ & $8 \pm 1$ & 0.037 \\
5.dk Apgar & $8 \pm 1$ & $8 \pm 1$ & 0.858 & $8 \pm 1$ & $9 \pm 1$ & 0.029 \\
Hemoglobin & $13.15 \pm 1.50$ & $13.30 \pm 1.60$ & 0.836 & $13.15 \pm 1.50$ & $11.75 \pm 1.80$ & 0.006 \\
(mg/dl) & & & & & & \\
Lökosit $\left(10^{3} / \mu \mathrm{L}\right)$ & $1092 \pm 4.24$ & $11.57 \pm 1.64$ & 0.458 & $10.92 \pm 4.24$ & $10.59 \pm 3.22$ & 0.900 \\
Lenfosit $\left(10^{3} / \mu \mathrm{L}\right)$ & $2.48 \pm 1.95$ & $3.08 \pm 2.45$ & 0.458 & $2.48 \pm 1.95$ & $2.56 \pm 2.42$ & 0.86 \\
Nötrofil $\left(10^{3} / \mu \mathrm{L}\right)$ & $7.93 \pm 4.76$ & $8.78 \pm 2.84$ & 0.680 & $7.93 \pm 4.76$ & $7.72 \pm 2.69$ & 0.900 \\
Trombosit(10 $/ \mu \mathrm{L})$ & $195.5 \pm 89$ & $256 \pm 99$ & 0.083 & $195.5 \pm 89$ & $246 \pm 69$ & 0.262 \\
MPV(fl) & $11.7 \pm 0.8$ & $10.55 \pm 1$ & 0.010 & $11.7 \pm 0.8$ & $10.7 \pm 1.20$ & 0.015 \\
Nötrofil/Lenfosit & $2.5 \pm 2.22$ & $2.34 \pm 1.02$ & 0.837 & $2.5 \pm 2.22$ & $2.62 \pm 2$ & 0.860 \\
Trombosit/Len- & $89.7 \pm 50.91$ & $95.74 \pm 69.81$ & 0.621 & $89.7 \pm 50.91$ & $85.38 \pm 63.39$ & 0.762 \\
fosit & & & & & & \\
Trombosit/Nötrofil & $29.27 \pm 13.41$ & $32.54 \pm 9.66$ & 0.564 & $29.27 \pm 13.41$ & $32.48 \pm 12.67$ & 0.450 \\
Trombosit/MPV & $16.68 \pm 7.61$ & $23.91 \pm 10.05$ & 0.048 & $16.68 \pm 7.61$ & $23.75 \pm 7.03$ & 0.058 \\
Sistolik Kan ba- & $160 \pm 10$ & $140 \pm 0$ & 0.001 & $160 \pm 10$ & $110 \pm 10$ & $<0.001$ \\
sinci(mmHg) & & & & & & \\
$\begin{array}{l}\text { Diastolik Kan ba- } \\
\text { sinc1(mmHg) }\end{array}$ & $110 \pm 10$ & $90 \pm 10$ & 0.025 & $110 \pm 10$ & $70 \pm 10$ & $<0.001$ \\
\hline & & & & & & \\
\hline
\end{tabular}

Ort(IQR): Verilerin ortanca değerleri (Çeyrekler arası aralık)

PE hastaları şiddetli ve hafif olmak üzere 2 grup olarak incelendiğinde; şiddetli PE grubunda hafif PE grubuna göre MPV değerinin anlamlı olarak fazla; PLT/MPV oranının ise anlamlı olarak daha düşük olduğu saptandı. Bu iki PE grupları arasında hemoglobin değerleri açısından fark saptanmadı (Tablo 4).

\section{TARTIŞMA VE SONUÇ}

PE obstetri kliniklerinde maternal-fetal-neonatal morbidite ve mortaliteyi etkileyebilen önemli bir acildir. Bu sebeple PE'yi erken dönemde tanıyabilmek, zamanında müdahale edebilmek önem kazanmıştır. Doğumun olduğu her merkezde PE hastaları ile karşılaşılabilir, birçok sağlık kuruluşunda yapılabilen rutin kan tahlillerinin PE tanısında olası tanısal önemleri PE hastalarına yaklaşımda farkındalığı artırabilir.

PE geniş bir yelpazeye sahiptir, hafif PE sıklıkla tedavisi rahat uygulanabilen doğum yöntemlerini değiştirmeyen ve maternal fetal morbidite- mortaliteyi çok etkilemeyen daha IIımlı bir tabloya sebep olurken şiddetli PE acil doğum kararı alınmasına sebep olan, tedavi ve takibinde üçüncü düzey hastane gerekliliği doğuran ve maternal- fetal morbidite -mortaliteyi etkileyebilen bir ciddi obstetrik acildir.

PE grubunda, PE'nin bir semptomu ve kriteri olan sistolik ve diyastolik kan basıncı kontrol grubuna göre anlamlı olarak yüksek bulundu. 
PE hastalarında sıklıkla doğum beklenen tarihten erken olmaktadır. Neonatal sonuçlarla ilgili olarak, beklendiği gibi PE grubunda erken doğuma bağlı daha düşük doğum ağırlığı, Apgar skoru saptanmaktadır. Daha önceden yapılan çalışmalarda, PE ile komplike bir gebelikten sonra doğan çocukların, komplike olmayan bir hamilelikten sonra doğan çocuklara kıyasla ortalama\% 5 daha düşük doğum ağırlığına sahip olduğunu gösterilmiştir $(8,9)$. Ve yine doğum şekli sıklıkla sezaryen doğum şeklindedir, bu durum erken gebelik haftasında gelişen PE varIığına, daha önceden yaşanmış PE'ye bağı geçirilmiş sezaryen öyküsüne ve kadın hastalıkları ve doğum doktorlarının olumsuz gebelik sonuçlarını en aza indirme istekleri ile açıklanabilir(8).

Gebelikte hematolojik, immünolojik ve inflamatuar değişiklikler fizyolojik olarak gözlemlenebilir. Ancak preeklampsi etyolojisi hakkında yapılan araştırmalar sonucunda kabul gören hipotezler içerisinde; maternal, paternal ve fetal dokular arasındaki immünolojik toleransın uyumsuz olması ve normal gebeliğin kardiyovasküler veya inflamatuar değişikliklerine maternal uyum bozukluğu yer almaktadır.

Preeklampsi hastalarında immünolojik faktörler üzerine yoğunlaşma, paternal antijenlere maruz kalma süresinin preeklampsiye karşı koruma sağlayabileceği gözlemine dayandırılmıştır. Nullipar kadınlarda, gebelikler arasında eş değiştiren kadınlarda ve intrasitoplazmik sperm enjeksiyonu yoluyla gebe kalan kadınlarda paternal antijene daha az maruziyet nedeniyle preeklampsi riskinin daha yüksek olduğu bildirilmektedir (10).

Normal gebeliklerde T-helper 1 (Th1) ve T-helper 2 (Th2) lenfosit dengesi Th2 lehinedir. Preeklampside ise Th1 hücrelerin aktivasyonu Th2' lerden fazladır (31). Yani preeklampside sitokin özellikleri, inflamasyonu indükleyen tip 1 sitokinlerin üretiminin baskın olduğunu, inflamasyonu düzenleyen tip 2 sitokinlerin üretiminin ise baskılandığını göstermektedir (10).

Sağıklı gebeliklerde aynı yaş grubundaki sağlıklı kadın popülasyonuna göre inflamatuar sürecin arttığı bilinen bir gerçektir. Preeklampsi de ise indüklenmiş inflamatuar sürece bağlı olarak inflamasyon belirtileri daha abartilı olabilir. Maternal enfeksiyonlar bu sistemik bir inflamatuar yanıtı daha da indükleyebilir. Yapılan bir metaanalizde idrar yolu enfeksiyonu ve periodontal hastalı̆ı olan hamile kadınlarda preeklampsi riskinin arttığını bildirmiştir (11).

Hematolojik parametreler incelendiğinde bazı çalışmalarda PE'li gebelerde hemoglobin seviyelerinin yükseldiği, trombosit sayısının düştüğü ve lökosit sayısının artıığı tespit edilmiştir $(12,13)$. Ve normal gebelikte olduğundan daha fazla lökosit sayısındaki artışın esas olarak nötrofil sayısındaki artıştan kay- naklandığı bildirilmiştir(12,14,15). Diğer taraftan hemoglobin ve trombosit sayısının yaşanılan coğrafik bölge, etnik köken ve beslenme alışkanlıkları ilişkili olarak değişebildiğini bildiren çaıışmada bulunmaktadır (16).

Çalışmamızda PE grubu kontrol grup ile karşılaştııılığında sadece hemoglobin değerinin istatistiksel anlamlı olarak yüksek olduğu bulunmuştur, trombosit düşüklüğü, lökosit ve nötrofil yüksekliği saptanmış ancak istatistiksel anlamlı fark saptanamamıştır. Yapılan çalışmalarda klinik olarak PE tablosu başlamadan önce trombositlerin aktif hale gelerek sayılarının arttığı ve bu durumun PE için bir belirteç olarak kullanımasını sağlayabileceği bildirilmiştir $(17,18)$. Buna ek olarak trombosit aktivasyonun diğer bir göstergesi olarak kabul edilen MPV değerinin de, inflamatuar bir belirteç olarak kabul edilerek, kronik inflamatuar süreçte arttığı bildirilmiştir (18). PE hastalarında MPV değerinin kontrol gruba göre yüksek olduğunu bildiren çalışmalar olduğu gibi, MPV ile ilişki saptanmayan çalışmalarda bulunmaktadır $(13,18,19,20,21)$. Çalışmamızda şiddetli PE grubunda MPV değeri istatistiksel anlamlı olarak hafif PE ve kontrol gruplarına göre daha yüksek saptandı. Altınbaş ve arkadaşları ise çalışmalarında gebelikte MPV düzeyinin arttığını ancak hafif ve şiddetli preeklampsiyi ayırt etmede rolü olmadığını veya preeklampsinin ilerlemesini gösteren bir belirteç olmadığını bildirmiştir (22).

Yapılan yayınlarda ülseratif kolit, pankreatit ve iskemik durumlarda sistemik inflamatuar yanıtın periferik belirteçleri olarak nötrofil/lenfosit, trombosit/lenfosit oranlarının kullanıldığu görülmüştür(13,23,24) İnflamatuar belirteç olarak değerlendirilebilen; trombosit/lenfosit, trombosit/nötrofil ve nötrofil/lenfosit oranları incelendiğinde çalışmamızda gruplar arasında farklıık tespit edilmedi. Sadece şiddetli ve hafif PE grupları kendi aralarında karşılaştııılığında trombosit/MPV oranında anlamlı fark saptandı, şiddetli PE grubunda bu oran anlamlı derecede düşük bulundu. Literatür incelendiğinde bu oranların PE ve kontrol grup karşılaştırmalarında tam bir fikir birliği olmadığı gözlenmiştir. PE ve kontrol grup arasında fark olmadığını bildiren çalışmaların yanında (19), özellikle nötrofil/lenfosit oranlarının PE gruplarında yüksek olduğunu bildiren yayınlarda mevcuttur $(20,21)$. Ancak preeklampsi etyolojide yer alan yetersiz maternal trofoblastik invazyon, plasental iskemi ve sistemik sitokin dengesizliği ve sistemik immün maladaptasyona değişen hematolojik parametreleri açıklamaya ışık tutmakla birlikte gebelikte gelişebilecek enfeksiyon ya da var olan immünolojik hastalıklarda da ek olarak bu parametrelerin etkilenebileceği unutulmamalıdır.

Sonuç olarak biz çalışmamızda maternal-fetal morbidite ve 
mortaliteyi ciddi düzeyde etkileyen şiddetli preeklamsi hastalarında; tüm sağlık kuruluşlarında kolayca ulaşılabilen ve hızlı sonuç alınabilen tam kansayımı parametrelerinden MPV değeri ve trombosit/MPV oranın yol gösterici belirteç olarak kullanılabileceğini ancak diğer inflamatuar belirteçler olarak kabul edilen trombosit/lenfosit, trombosit/ nötrofil ve nötrofil/lenfosit oranlarının tanı koymada yetersiz olduğu sonucuna ulaştık.

Özellikle şiddetli PE hastalarında kullanışı ve uygun maliyetli belirteçler olarak kabul edilebilecek MPV değerleri, nötrofil/ lenfosit ve trombosit/MPV oranının rutin kullanım olasılığını belirlemek için homojen hasta popülasyonları ile daha kapsamlı çalışmalara intiyaç vardır.

\section{KAYNAKLAR}

1. Cunnigham FG, Leveno J, Bloom SL, et al. Williams Obstetrics. New York, USA: McGraw Hill Medical; 2010:706-711.

2. Gogoi P, Sinha P, Gupta B, et al. Neutrophil-to-lymphocyte ratio and platelet indices in pre-eclampsia. Int J Gynaecol Obstet. 2019;144(1):16-20.

3. American College of Obstetricians and Gynecologists' Committee on Practice Bulletins-Obstetrics. Gestational Hypertension and Preeclampsia: ACOG Practice Bulletin, Number 222. Obstet Gynecol. 2020 ;135(6): e237-e260.

4. Croke, Lisa M. "Gestational hypertension and preeclampsia: a practice bulletin from ACOG." American family physician 100.10 (2019): 649-650.

5. Dekker GA, Sibai BM. Etiology and pathogenesis of preeclampsia: current concepts. Am J Obstet Gynecol 1998; 179:1359-75. (Level III)

6. Sargent IL, Germain SJ, Sacks GP, et al. Trophoblast deportation and the maternal inflammatory response in pre-eclampsia. J Reprod Immunol 2003; 59: 153-60. (Level III)

7. Chua S, Wilkins T, Sargent I, et al. Trophoblast deportation in pre-eclamptic pregnancy. Br J Obstet Gynaecol 1991; 98:9739. (Level III)

8. Chandra I, Sun L. Preterm and term preeclampsia: differences in biochemical parameter and pregnancy outcomes. Postgrad Med. $2018 ; 130(8): 703-707$.

9. Odegard RA, Vatten LJ, Nilsen ST, et al. Preeclampsia and fetal growth. Obstet Gynecol. 2000;96(6):950-5. PubMed PMID: 11084184.

10. Saito S, Shiozaki A, Nakashima A, et al. The role of the immune system in preeclampsia. Mol Aspects Med. 2007 Apr;28(2):192-209.

11. Conde-Agudelo A, Villar J, Lindheimer M. Maternal infection and risk of preeclampsia: systematic review and metaanalysis. Am J Obstet Gynecol. 2008 Jan;198(1):7-22.

12.Canzoneri BJ, Lewis DF, Groome L, et al. Increased neutrophil numbers account for leukocytosis in women with preeclampsia. Am J Perinatol. 2009; 26:729-32.

13. Yavuzcan A, Cağlar M, Ustün Y, et al. Mean platelet volume, neutrophil-lymphocyte ratio and platelet-lymphocyteratio in severe preeclampsia. Ginekol Pol. 2014;85: 197-203.

14.Lurie S, Frenkel E, Tuvbin Y. Comparison of the differential distribution of leukocytes in preeclampsia versus uncomplicated pregnancy. Gynecol Obstet Invest. 1998;45(4):229-231.

15. Edelstam G, Lowbeer C, Kral G, et al. New reference values for routine blood samples and human neutrophilic lipocalin during third-trimester pregnancy. Scand J Clin Lab Invest. 2001, 61 (8), 583-592.

16. Järemo $P$, Lindahl $T L$, Lennmarken $C$, et al. The use of platelet density and volume measurements to estimate the severity of pre-eclampsia. Eur J Clin Invest. 2000; 30:1113-8.

17. Felfernig-Boehm D, Salat A, Vogl S, et al. Early detection of preeclampsia by determination of platelet aggregability. Thromb Res 2000; 98:139-46.

18.Gezer C, Ekin A, Özeren M, et al. Erken ve geç preeklampside birinci trimester inflamasyon belirteçlerinin yeri. Perinatoloji Dergisi,2014 22(3), 128-132.

19.Yücel B, Ustun B. Neutrophil to lymphocyte ratio, platelet to lymphocyte ratio, mean platelet volume, red cell distribution width and plateletcrit in preeclampsia. Pregnancy Hypertens. 2017; 7:29-32.

20. Kirbas A, Ersoy AO, Daglar K, et al. Prediction of Preeclampsia by First Trimester Combined Test and Simple Complete Blood Count Parameters. J Clin Diagn Res. 2015;9(11): QC203.

21. Mannaerts D, Heyvaert S, De Cordt C, et al. Are neutrophil/ lymphocyte ratio (NLR), platelet/lymphocyte ratio (PLR), and/ or mean platelet volume (MPV) clinically useful as predictive parameters for preeclampsia? J Matern Fetal Neonatal Med. 2019;32(9):1412-1419.

22.Altınbas S, Toğrul C, Orhan A, et al.. Increased MPV is not a significant predictor for preeclampsia during pregnancy. J Clin Lab Anal. 2012;26(5):403-6. 
23. Celikbilek M, Dogan S, Ozbakır O, et al. Neutrophil-lympho- 24. Imtiaz F, Shafique K, Mirza SS, et al. Neutrophil lymphocyte cyte ratio as a predictor of disease severity in ulcerative colitis. ratio as a measure of systemic inflammation in prevalent chroJ Clin Lab Anal. 2013, 27 (1), 72-76. nic diseases in Asian population. Int Arch Med. 2012, 5 (1), 2. 